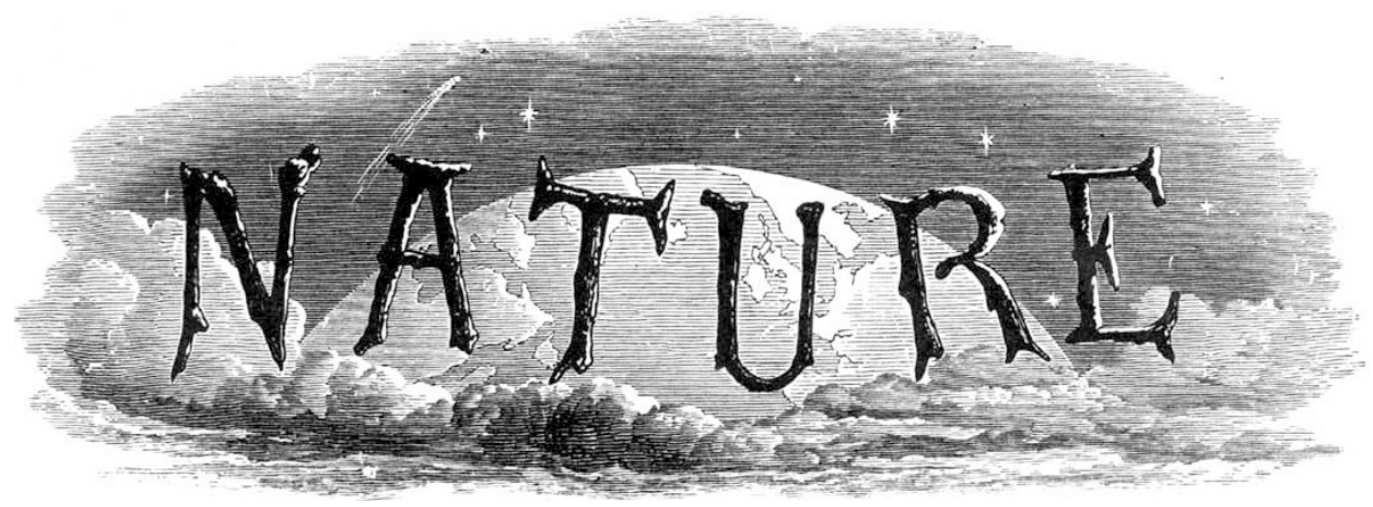

A WEEKLY ILLUSTRATED JOURNAL OF SCIENCE.

"To the solid ground

Of Natire trusts the mind which builds for aye."-WordsworTr.

THURSDAY, JANUARY 5, 1922.

Editorial and Publishing Offices:

MACMILLAN \& CO., LTD.,

ST. MARTIN'S STREET, LONDON, W.C. 2.

Advertisements and business letters should be addressed to the Publishers.

Editorial communications to the Editor.

Telegraphic Address: PHUSIS, LONDON.

Telephone Number: GERRARD 8830.

\section{Education and the Nation.}

$\mathrm{O}$ N Sunday, November $27, \mathrm{Mr}$. Fisher, President of the Board of Education, speaking in Whitefield's Mission, London, on "Our Schools," said :

"Education is a great unifying influence, not only between classes, but also between nations. The estranging influences between man and man are not rooted in the externals of situation or wealth, but are founded in differences of intellectual acquisition and of intellectual and moral outlook. There still persists the delusion that the education of the poor must be different, not only in amount, but also in quality, from the education which is at the service of the more affluent members of the nation. But the poor, even more than the rich, stand in need of the best possible education, since they lack the home advantages of the wealthy. Indeed, in the crowded areas of the cities the school plays an even greater part than the home in the formation of the national mind. The elementary school may not give all the results we are entitled to expect, though there has been great progress made in the last generation through the development of a spirit of humanism in the schools. It will not become fruitful in result until something is done to provide education for the vital period of adolescence."

This was the spirit that animated Mr. Fisher in the drafting of the measure which culminated in the Education Act of IgI8, and served to mark the public appreciation of the benefits of education and the great progress made since the Education Act of I902. Mr. Fisher stated that day continuation schools were provided for in the Education Act of $19 \mathrm{~s} 8$, but, owing to financial circumstances, at the present time they could not develop the system adequately. $\mathrm{He}$ added that the children of the nation needed more schools, more books, and better teachers, and if the nation was in earnest they would assuredly get them in time. Yet the Board of Education has continually thwarted the progressive efforts of the more enterprising local authorities in the provision of new schools; it hampers the provision of Central Schools in London even where such provision can be made by the reorganisation of existing elementary schools, and it checks the development of schools where physically defective children can receive remedial treatment.

There has arisen-and it is an extremely hopeful sign of the public interest in the value of education - a strong demand for the advantages of higher education, and thousands of children in all parts of the country are eager for admission to secondary schools; but the Board offers no encouragement to that end; in fact, it has sanctioned the raising of the fees in such schools, thereby preventing the poorer children from taking advantage of them, and

NO. 2723 , VOL. IO9] 
the same policy is being pursued with respect to the much-needed nursery schools for children under five. Day continuation classes during two years, as provided for by the Act, for young people who have left the elementary school at fourteen in order to enter into employment, are, except in the London area, practically a dead letter, the Board refusing its sanction to the fixing of the appointed day.

The Committee of business men appointed by the Chancellor of the Exchequer, with Sir Eric Geddes as chairman, to consider the national expenditure with a view to drastic economies in the various spending departments has presented its Report to the Cabinet, but its full details have not been made public. It is rumoured that there is a proposed reduction in the total estimates for the year 1922-23 of $195,000,000 l$., of which the education estimates are responsible for $16,000,000 l$. As showing the spirit in which this question has been approached, Lord Inchcape, one of the influential members of this Committee, and the chairman of the P. and $O$., said, at a recent meeting of the shareholders of his company, that "education is an excellent thing in its way, but there are limitations to its economic usefulness." Lord Haldane, at a meeting held at London University on December I 7, arranged by the London Head 'Teachers' Association, dealt effectively with Lord Inchcape's observations, and showed how much the progress of the nation in every department of industrial life and even in his own particular business of shipping has been due to education. $\mathrm{He}$ said :

" Lord Inchcape could not sail a single steamer but for the education of the great inventors and men of science which made it possible, nor would his staff know how to handle the instruments but for the training they have received from their teachers. Modern business cannot stand still, neither can education. Other nations realise the value of education, and will get ahead of us if we do not; if we neglect it, hard times will come, when we shall be driven belatedly to reverse the policy threatened to-day in order to recover our resources and progress, which will have failed us through our misunderstanding of the true meaning of economy."

In this respect the decision of the Treasury to reduce the grant to the universities from I, 500,000l. to $1,200,000 l$. will seriously hamper these institutions in their endeavour to get and to retain competent teachers, and will impede scientific research on which a further advance in knowledge and especially industry, alike in the spheres of manufac- tures and of agriculture, so largely depends. The joint meeting of the general council of the Trade Union Congress and the Labour Party Executive, held in London on December I4, views this policy with profound disapproval, which can do virtually nothing, it says, "to relieve the national finances, but which will be a serious blow to higher education."

An important manifesto has recently been issued by the Teachers' Registration Council, entitled " Education and National Life," for presentation to his Majesty's Ministers and in the expectation that it will be signed by many eminent men and women. It refers to the national danger which attends any attempt to reduce expenditure on education, and urges that the recent extension of the franchise has made it the more necessary to open all possible avenues of knowledge and enlightenment as preventives of error and-half-truths in politics, economics, and social relationships. A complete and generous system of education will fortify the State against civil unrest and strife, while serving to widen the vision and enrich the lives of individuals. We were led in the tragic ordeal of the war to perceive the faults of our previous educational system and to frame the new proposals embodied in the Education Act of 19r8. But that measure is not really in operation, and the newly awakened desire of working people for further knowledge is left unsatisfied. The signatories recognise the need for a careful survey of our national resources and for thrift in all public and private expenditure, but hold that thrift should be exercised with discrimination and not so as to curtail educational opportunity. They conclude with the desire to see our country take its place in the van of civilised and enlightened communities and regard public expenditure on education as a wise investment which will bring to this and succeeding generations the rich rewards of civic greatness and private contentment.

It is to be hoped that this weighty manifesto from an influential body of well-wishers to education may receive speedy and favourable consideration at the hands of the Government, in order that the provisions of the Education Act of 19r 8 may be put into practical operation without further delay, and also that the full grant of $1,500,000 l$. be restored to the universities so as to encourage research in all departments of knowledge and give them the opportunity of fully developing their resources in the vital and permanent best interests of the nation. 